Int. J. Electrochem. Sci., 14 (2019) 5613 - 5628

International Journal of

ELECTROCHEMICAL

SCIENCE

$\underline{\text { WWW.electrochemsci.org }}$

\title{
Phosphomolybdic Acid coupling with Vulcan XC72 Carbon as Superior Catalyst to Enhance ORR Activity and Performance of MFC
}

\author{
Kai Zhang ${ }^{2}$, Yongkui Huang ${ }^{2}$, Daijun Zhang ${ }^{1,2, *}$, Aqiang Ding ${ }^{1,2}$, Xiaoting Zhang ${ }^{2}$, Peili Lu ${ }^{1,2}$ \\ ${ }^{1}$ Key Laboratory of Coal Mine Disaster Dynamics and Control, Chongqing University, Chongqing, \\ 400044, PR China. \\ ${ }^{2}$ College of Resource and Environmental Science, Chongqing University, Chongqing, 40044, PR \\ China. \\ *E-mail: dzhang@ @qu.edu.cn
}

doi: $10.20964 / 2019.06 .27$

Received: 6 February 2019 / Accepted: 31 March 2019 / Published: 10 May 2019

\begin{abstract}
Microbial fuel cell (MFC) is an emerging technology that can treat wastewater and recover energy simultaneously However, there are many factors that limit its application, among which cathode catalysts are one of the main obstacles. In this study, $\mathrm{H}_{3} \mathrm{PMo}_{12} \mathrm{O}_{40} /$ Vulcan XC72 carbon (PMo/CB) material was successfully prepared by a feasible process and used as efficient catalyst on oxygen reduction reaction (ORR) to improve the performance of MFC. The electrochemical performance of $\mathrm{PMo} / \mathrm{CB}$ and $\mathrm{Pt} / \mathrm{C}$ were evaluated by LSV, EIS, and Tafel plot. The results showed that the ORR activities of samples were following the order of $\mathrm{PMo} / \mathrm{CB}-2>\mathrm{Pt} / \mathrm{C}>\mathrm{PMo} / \mathrm{CB}-3>\mathrm{PMo} / \mathrm{CB}-1>\mathrm{PMo} / \mathrm{CB}-4>\mathrm{CB}$. Moreover, $\mathrm{PMo} / \mathrm{CB}$ exhibited a high durability compared to $\mathrm{Pt} / \mathrm{C}$ in MFC after 4 months of operation. Finally, the catalytic reaction mechanism of $\mathrm{PMo} / \mathrm{CB}$ was discussed. The results demonstrated the high ORR activity of the sample could be attributed to the favorable specific surface area of $\mathrm{CB}$ and the effect of electrostatic coupling between $\mathrm{PMo}$ and $\mathrm{CB}$, which enhanced the adsorption and reduction of $\mathrm{O}_{2}$. Therefore, $\mathrm{PMo} / \mathrm{CB}$ will be a promising cathode ORR catalyst for microbial electrochemical system.
\end{abstract}

Keywords: Phosphomolybdic acid, Vulcan XC72 carbon, Oxygen reduction reaction, Microbial fuel cells.

\section{FULL TEXT}

(C) 2019 The Authors. Published by ESG (www.electrochemsci.org). This article is an open access article distributed under the terms and conditions of the Creative Commons Attribution license (http://creativecommons.org/licenses/by/4.0/). 